\title{
BUBBLES AND BUBBLE PRESSURES IN ANTARCTIC GLACIER ICE
}

\author{
By Anthony J. Gow \\ (Research Division, Snow and Ice Branch, U.S. Army Cold Regions Research and \\ Engineering Laboratory, Hanover, New Hampshire 03755, U.S.A.)
}

Abstract. Application of the gas law to fourth-place density measurements of ice samples from two deep drill holes at "Byrd" station and "Little America V", Antarctica, shows that virtually all density increase beyond the pore close-off density $\left(0.830 \mathrm{~g} \mathrm{~cm}^{-3}\right)$ can be attributed to compression of the entrapped bubbles of air. Data from "Byrd" station also indicate that the lag between overburden pressure and bubble pressure, initially $4-5 \mathrm{~kg} \mathrm{~cm}^{-2}$ at pore close-off, diminishes to less than $1.0 \mathrm{~kg} \mathrm{~cm}^{-2}$ at about $200 \mathrm{~m}$ depth. By substituting the overburden pressure for the bubble pressure in the pressure-density relationship based on the gas law, one can determine ice densities below $200 \mathrm{~m}$ more accurately than they can be measured per se on cores, because of the relaxation that occurs in samples recovered from high confining pressures. This relaxation, resulting in a progressive increase in the bulk volume of the ice with time, is generally attributed to decompression of the entrapped air bubbles following removal of the ice from high confining pressures. However, calculations of the stress in ice due to bubble pressure, together with measurements of bubble sizes in cores from various depths at "Byrd" station, both tend to indicate that there has been negligible decompression of the inclosed bubbles. It is suggested that most of this relaxation may be due to the formation of micro-cracks in the ice. Anomalous bubble pressure-density relations at "Little America V" tend to confirm abundant petrographic evidence of the existence of considerable deformation in the upper part of the Ross Ice Shelf.

Studies of crystal-bubble relations at "Byrd" station revealed that the concentration of bubbles in ice remains remarkably constant at approximately 220 bubbles $/ \mathrm{cm}^{3}$. Bubbles and crystals were found to be present in approximately equal numbers at pore close-off at $64 \mathrm{~m}$ depth, at which level the average bubble diameter was $0.95 \mathrm{~mm}$, decreasing to $0.49 \mathrm{~mm}$ at $116 \mathrm{~m}$ and to $0.33 \mathrm{~mm}$ at $279 \mathrm{~m}$. Despite a ten-fold increase in the size of crystals between 64 and $279 \mathrm{~m}$, the bubbles showed no tendency to migrate to grain boundaries during recrystallization of the ice. The observation that most of the bubbles had assumed substantially spherical shapes by $120 \mathrm{~m}$ depth points to essentially hydrostatic conditions in the upper layers of the ice sheet at "Byrd" station.

RÉsumé. Des bulles et la pression des bulles dans la glace des glaciaires Antarctiques. L'application de la loi des gaz à la mesure jusqu'à la quatrième décimale de la densité de échantillons de glace prélevés dans des trous de forage profond effectués à la station "Byrd" et à "Little America V" dans l'Antarctique, montre que les augmentations de densité au delà de la densité de fermeture des pores $\left(0,830 \mathrm{~g} \mathrm{~cm}^{-3}\right)$ peuvent pratiquement toutes être attribuées à la compression des bulles d'air enfermées dans la glace. Des données obtenues à la station "Byrd" indiquent également que le retard entre la pression de surcharge et la pression des bulles, qui est à l'origine de 4 à $5 \mathrm{~kg} \mathrm{~cm}^{-2}$ à la fermeture des pores, diminue jusqu'à moins de $\mathrm{I} \mathrm{kg} \mathrm{cm}^{-2}$ à une profondeur d'environ $200 \mathrm{~m}$. La substitution de la pression des bulles par la pression de surcharge dans la relation pression-densité basée sur la loi des gaz permet de déterminer les densités de glace au delà de $200 \mathrm{~m}$ avec plus de précision que ne le permettrait une mesure à vue sur des échantillons prélevés à cause de la relaxation qui se produit dans des échantillons tirés des situations où ils sont soumis à des pressions élevées. Cette relaxation, qui provoque une augmentation progressive du volume total de la glace avec le temps, est généralement attribuée à la décompression des bulles d'air enfermées dans la glace après retraît de l'échantillons des conditions de pression élevées auxquelles il était soumis. Toutefois, des calculs des tensions présentes dans la glace et dues à la pression des bulles, ainsi que des mesures de dimensions des bulles dans des échantillons de glace prélevés à différentes profondeurs à la station "Byrd", indiquent que la décompression à laquelle sont soumises les bulles est négligeable. Les résultats indiquent que la relaxation peut être causé par la formation de fentes microscopiques dans la glace. Des relations anormales entre la pression des bulles et la densité obtenues à "Little America V" confirment les indications petrographiques abondantes tendant à prouver l'existence de déformations considérables dans la partie supérieure du Ross Ice Shelf.

L'étude des relations bulles-cristaux à la station "Byrd" révèle que la concentration de bulles dans la glace reste remarquablement constante à environ 220 bulles par $\mathrm{cm}^{3}$. Des bulles et des cristaux ont été trouvés en nombre à peu près égal à des pressions de fermeture des pores à une profondeur de $64 \mathrm{~m}$, profondeur à laquelle le diamètre moyen des bulles était de $0,95 \mathrm{~mm}$, et diminuait jusqu'à $0,49 \mathrm{~mm}$ à I I $6 \mathrm{~m}$ et $0,33 \mathrm{~mm}$ à $279 \mathrm{~m}$. Malgré le décuplement de la taille des cristaux entre 64 et $279 \mathrm{~m}$, les bulles ne montrèrent aucune tendance à la migration vers les limites des grains durant la recristallisation de la glace. L'observation que la majeure partie des bulles avaient acquis des formes essentiellement sphériques à partir de $120 \mathrm{~m}$ de profondeur montre l'existence de phénomènes surtout hydrostatiques dans les niveaux supérieurs de la nappe de glace à la station "Byrd".

Zusammenfassung. Blasen und Blasendruck in antarktischen Gletschereis. Die Anwendung des Gasgesetzes auf viertstellige Dichtemessungen in Eisproben, aus zwei Tiefbohrlöchern im Gebiet der "Byrd" Station und bei "Little America V", Antarktika zeigt, dass praktisch alle Steigerungen der Dichtezunahme über die Porenschliessdichte $\left(0,830 \mathrm{~g} \mathrm{~cm}^{-3}\right)$ hinaus auf die Kompression der eingeschlossenen Luftblasen zurückgeführt werden kann. Aus den von der "Byrd" Station gewonnenen Daten geht ebenfalls hervor, dass sich 
der Minderbetrag zwischen Überlagerungsdruck und Blasendruck, der anfangs 4-5 $\mathrm{kg} \mathrm{cm}^{-2}$ bei Porenschliessung beträgt, auf weniger als $\mathrm{r}, \mathrm{O} \mathrm{kg} \mathrm{cm} \mathrm{m}^{-2}$ in etwa $200 \mathrm{~m}$ Tiefe verringert. Ersetzt man in der auf dem Gasgesetz basierenden Druck-Dichte-Beziehung den Blasendruck durch den Überlagerungsdruck, so kann man Eisdichten unterhalb einer Tiefe von $200 \mathrm{~m}$ mit grösserer Genauigkeit bestimmen als durch Messung an den Bohrkernen selbst, und zwar wegen der Entspannung, die in Proben eintritt, die hohen Einschliessungsdrücken entnommen werden. Diese Entspannung, die sich in einer progressiven Zunahme des Eisvolumens der Zeit äussert, wird im allgemeinen auf die Dekompression der eingeschlossenen Luftblassen nach der Entnahme des Eises aus hohen Einschliessungsdrücken zurückgeführt. Berechnungen der durch den Blasendruck im Eis erzeugten Spannungen sowie in Verbindung damit durchgeführte Messungen der Blasengrösse in Bohrkernen aus verschiedenen Tiefen im Gebiet der "Byrd" Station scheinen jedoch darauf hinzudeuten, dass die Dekompression in den eingeschlossenen Luftblasen nur unbedeutend ist. Es wird vermutet, dass diese Entspannung in erster Linie auf der Bildung von Mikrorissen im Eis beruht. Anomale Blasendruck-Dichte-Beziehungen im Gebiet von "Little America V" scheinen die in reichen Masse vorhandenen petrographischen Beweise für das Vorhandensein einer beträchtlichen Deformation im oberen Teil des Rosseisschelfes zu bestätigen.

Auf der "Byrd" Station durchgeführte Untersuchungen der Kristall-Blasen-Beziehungen haben ergeben, dass die Konzentration der Blasen im Eis mit 220 Blasen pro $\mathrm{cm}^{3}$ bemerkenswert konstant bleibt. Blasen und Kristalle wurden in etwa gleicher Anzahl bei Porenschliessdruck in $64 \mathrm{~m}$ Tiefe festgestellt; auf diesem Niveau betrug der mittlere Blasendurchmesser $0,95 \mathrm{~mm}$, der sich in $116 \mathrm{~m}$ Tiefe auf $0,49 \mathrm{~mm}$ und in $279 \mathrm{~m}$ Tiefe auf $0,33 \mathrm{~mm}$ verringerte. Trotz einer zehnfachen Vergrösserung der Kristalle zwischen 64 und $279 \mathrm{~m}$ zeigten die Blasen keine Tendenz, während der Rekristallisation des Eises zu den Korngrenzen zu wandern. Die Beobachtung, dass die meisten Blasen bei $120 \mathrm{~m}$ Tiefe fast Kugelgestalt angenommen hatten, deutet auf im wesentlichen hydrostatische Verhältnisse in den oberen Schichten der Eisdecke im Gebiet der "Byrd" Station hin.

\section{INTRODUGTION}

Polar glacier ice is characterized by the widespread occurrence of air bubbles that are trapped initially during the process of transformation of snow to ice. The structure of consolidated snow (firn) is essentially sponge-like in that much of the pore space is intercommunicating, i.e. permeable. With increasing depth of burial, this pore space is gradually eliminated until the stage is reached where the snow is no longer permeable and the firn is said to have transformed into glacier ice. The freshly formed ice still contains io per cent by volume of air trapped in the form of discrete bubbles which become compressed as they sink deeper into the ice sheet. It is this compression of bubbles in the ice that is primarily responsible for additional increase in the bulk density of the ice.

An exceptional opportunity to study changes both in the pressure and in the distribution and structure of bubbles as a function of depth in the Antarctic ice sheet arose during the I.G.Y. (1957-58) when ice cores were obtained to depths of 308 and $254 \mathrm{~m}$ at "Byrd" station and "Little America V", respectively. Approximately Ioo samples of ice of density $>0.8_{30}$ $\mathrm{g} \mathrm{cm}^{-3}$ from both locations were used to obtain 4-place density measurements, and these data, in conjunction with observations of bubble structure in thin sections of ice, have been used to accomplish the following objectives:

i. To investigate the relationship between bubble pressure and the in situ overburden pressure, and to determine, if possible, the depth at which the difference in pressures is reduced to less than $\mathrm{I}-2 \mathrm{~kg} \mathrm{~cm}^{-2}$.

ii. To investigate the pattern of changes in the size, shape, number and distribution of air bubbles as a function of depth in the Antarctic ice sheet.

\section{Previous studies}

Studies of bubbles in glacier ice, including measurements of bubble pressure, have been made by a number of workers including Koch and Wegener (r930), Bader (r950), Shumskiy (1955), Coachman and others (1956), Scholander and others (1956), Langway (1958), Schytt (1958), Scholander and Nutt (1960), and Matsuo and Miyake (1966). Pressure measurements obtained by Schytt at Maudheim, and by Matsuo and Miyake at Syowa base, appear to be the only ones made so far on glacier ice from Antarctica. Schytt reasoned that, if all density increase beyond the pore close-off depth, i.e. for densities $>0.830 \mathrm{~g} \mathrm{~cm}^{-3}$, can be attributed to bubble compression (compressibility of ice is negligibly small in the upper 
200-300 $\mathrm{m}$ of the ice sheet), then the bubble pressure $P$ of any particular ice sample can be expressed as $P=P_{\mathrm{c}} V_{\mathrm{c}} / V$, where $P_{\mathrm{c}}$ and $V_{\mathrm{c}}$ are the bubble pressure and void ratio respectively at pore close-off and $V$ is the void ratio of the sample. Subsequent tests of this relationship by Schytt with samples from between 90.5 and $97 \mathrm{~m}$ at Maudheim revealed very satisfactory agreement between the measured and calculated pressures.

Direct measurements of bubble pressure, i.e. measurements of pressure within individual bubbles in glacier ice, have been made by Scholander and Nutt (1960) on samples from a number of Greenland icebergs. Most bubbles were found to have pressures of 4-5 atmospheres, though pressures as high as 20 atmospheres were recorded in some bubbles. However, most of the pressure measurements reported so far have been obtained indirectly from very precise determinations of the density of bubbly ice made in conjunction with measurements of the volume of air released upon melting the samples. Of these measurements, those made by Langway (1958, 1962) on core samples from "Site 2" in Greenland are probably the most accurate obtained so far on polar glacier ice. Langway reported pressures as high as 27 atmospheres in ice from $360.5 \mathrm{~m}$ depth but the major point of interest of his study was that in most of the samples tested the bubbles were seemingly compressed less than might have been expected from the weight of overlying snow and ice. Other conclusions reached by Langway as a result of this work were that the composition of the inclosed air in ice at "Site 2 " has remained constant for the last 900 years and that the mass of entrapped air also has remained unchanged and does not diffuse through the ice.

\section{Analytical Procedures}

In the present study no attempt was made to measure bubble pressures per se. However, it should be possible to calculate the average bubble pressure in a sample of ice if the density of that sample has been accurately determined, and if there are reasonably accurate data on the pore close-off density and pressure, and the variation of overburden pressure with depth.

If the density at pore close-off is denoted by $\gamma_{\mathrm{c}}{ }^{*}$ and the pressure in the bubbles at this depth is $P_{\mathrm{c}}$ (this is essentially equal to the average station pressure corrected for the depth at which the pores finally close off), then the average bubble pressure $P$ is:

$$
P=P_{\mathrm{c}} \frac{\gamma_{\mathrm{it}}-\gamma_{\mathrm{c}}}{\gamma_{\mathrm{c}}} \times \frac{\gamma}{\gamma_{\mathrm{it}}-\gamma}
$$

where $\gamma_{i t}$ is density of bubble-free ice at the in situ temperature and $\gamma$ is the density of the sample at the same temperature. This is, of course, equivalent to the expression $P=P_{\mathrm{c}} V_{\mathrm{c}} / V$ with the void ratios simply re-written in terms of density. Relationship (I) can be readily transformed to evaluate $\gamma$ and $\gamma_{c}$ if the various other parameters are known, e.g.

$$
\begin{gathered}
\gamma=\frac{P \gamma_{\mathrm{it}}}{P+P_{\mathrm{c}}\left(\frac{\gamma_{\mathrm{it}}}{\gamma_{\mathrm{c}}}-\mathrm{I}\right)}, \\
\gamma_{\mathrm{c}}=\frac{P_{\mathrm{c}} \gamma_{\mathrm{it}}}{P_{\mathrm{c}}+P\left(\frac{\gamma_{\mathrm{it}}}{\gamma}-\mathrm{I}\right)} .
\end{gathered}
$$

The original densities were determined by hydrostatic weighing of ice cores using highly purified iso-octane of density $0.7160 \mathrm{~g} \mathrm{~cm}^{-3}$ at $-10^{\circ} \mathrm{C}$ as the immersion liquid. These data are tabulated fully by Gow (in press) and are accurate to at least $\pm 0.00015 \mathrm{~g} \mathrm{~cm}^{-3}$.

* Bubble close-off and the firn-ice transition occur at essentially the same depth since impermeable firn is bubbly ice by definition. This transformation is observed to occur at densities of $0.82-0.84 \mathrm{~g} \mathrm{~cm}^{-3}$. It might be noted that this definition of ice is true only for samples of the dimensions of thin sections, i.e. of one or two grain diameters at most. In larger samples of firn, zero permeability may effectively be reached at somewhat lower densities, in which case some compression of bubbles may have already occurred before all pore spaces had become sealed off. 
All densities were corrected for in situ temperatures using the simplified expression of Butkovich (1957) for correcting for isopeizic density of ice between $0^{\circ}$ and $-30^{\circ} \mathrm{C}$. At "Byrd" station the in situ temperature of the ice remains essentially constant at $-28^{\circ} \mathrm{C}$ and the isopeizic density, $\gamma_{\mathrm{it}}$, of bubble-free ice at this temperature is $0.9204 \mathrm{~g} \mathrm{~cm}^{-3}$. At "Little America $\mathrm{V}$ ', however, temperatures in the ice shelf are not constant but increase from $-2 \mathrm{I}^{\circ} \mathrm{C}$ at $5^{2} \mathrm{~m}$ to $-2.0^{\circ} \mathrm{C}$ at the bottom (depth $25^{8} \mathrm{~m}$ ), causing a corresponding decrease of $\gamma_{i t}$ from 0.9195 to $0.9168 \mathrm{~g} \mathrm{~cm}^{-3}$.

\section{Results AND Discussion}

\section{"Byrd" station}

Rather than use relationship (I) to compute pressures from measured densities, relationship (2) was used instead to solve for $\gamma$ over a range of pressures of from I to 25 atmospheres. The calculated densities were matched with depth-density data from cores and the ice loads $(\sigma)$ appropriate to each density were then calculated. The absolute load was obtained by merely adding the average station pressure $\left(0.82 \mathrm{~kg} \mathrm{~cm}^{-2}\right)$ to the calculated ice loads. According to Langway's bubble-pressure data at "Site 2", pore close-off occurs at approximately $0.828 \mathrm{~g} \mathrm{~cm}^{-3}$. Observations on permeabilities of thin slices of core from "Byrd" station also indicated that the pores had closed off at much the same value, but in the absence of more precise data it was decided to evaluate (2) for three separate values of $\gamma_{\mathrm{c}}$, namely 0.820 ,

Table I. Bubble-pressure-Density Relationships in Ice Cores from "Byrd" Station, Antarctica. Bubblepressure Calculations Based on Pore Close-off Density $\gamma_{c}=0.825 \mathrm{~g} \mathrm{~cm}^{-3}$

Pressure-density computations using

$$
\begin{aligned}
\gamma & =\frac{P \gamma_{\mathrm{it}}}{P+P_{c}\left(\frac{\gamma_{\mathrm{it}}}{\gamma_{c}}-\mathrm{I}\right)}, \text { where } \\
\gamma_{\mathrm{it}} & =0.9204 \mathrm{~g} \mathrm{~cm}^{-3} \\
P_{c} & =0.82 \mathrm{~kg} \mathrm{~cm}^{-2}(0 \cdot 80 \text { atmos })
\end{aligned}
$$

\begin{tabular}{|c|c|c|c|c|c|}
\hline \multicolumn{2}{|c|}{$\begin{array}{c}\text { Pressure, } \\
P\end{array}$} & $\begin{array}{c}\text { Density, } \\
\gamma\end{array}$ & Depth & $\begin{array}{c}\text { Absolute load, } \\
\sigma+P_{c}\end{array}$ & $\begin{array}{c}\text { Pressure lag, } \\
\sigma+P_{c}-P\end{array}$ \\
\hline atmos & $\mathrm{kg} \mathrm{cm}^{-2}$ & $\mathrm{~g} \mathrm{~cm}^{-3}$ & $\mathrm{~m}$ & $\mathrm{~kg} \mathrm{~cm}-2$ & $\mathrm{~kg} \mathrm{~cm} \mathrm{~cm}^{-2}$ \\
\hline 0.80 & 0.82 & 0.825 & 63 & 5.01 & 4.19 \\
\hline 1.0 & 1.03 & 0.8425 & 65 & 5.18 & 4.15 \\
\hline 2.0 & 2.07 & o.8797 & 80 & $6.4^{8}$ & $4 \cdot 4^{I}$ \\
\hline 3.0 & 3.10 & $0.89^{29}$ & 89 & 7.28 & 4.18 \\
\hline 4.0 & $4 \cdot 13$ & 0.8996 & 99 & 8.18 & 4.05 \\
\hline 5.0 & 5.17 & 0.9037 & 106 & $8.8 \mathrm{I}$ & 3.64 \\
\hline 6.0 & 6.20 & 0.9064 & 113 & $9 \cdot 44$ & 3.24 \\
\hline 7.0 & 7.23 & 0.9084 & 122 & 10.27 & 3.04 \\
\hline 8.0 & 8.26 & 0.9099 & 127 & 10.71 & 2.45 \\
\hline 9.0 & $9 \cdot 30$ & 0.9110 & I 34 & 11.35 & 2.05 \\
\hline 10.0 & I0.33 & 0.9120 & 140 & I 1.90 & 1.57 \\
\hline I I.O & 11. 36 & 0.9127 & 148 & 12.63 & 1.27 \\
\hline 12.0 & 12.40 & $0.9^{1} 34$ & I 59 & 13.63 & I. 23 \\
\hline I 3.0 & 1 3.43 & 0.9139 & 164 & 14.09 & 0.66 \\
\hline 14.0 & I 4.46 & 0.9144 & I 75 & 15.08 & 0.62 \\
\hline 15.0 & I $5.5^{\circ}$ & $0.9^{1} 4^{8}$ & 186 & 16.10 & 0.60 \\
\hline 16.0 & 16.53 & $0.9^{1} 5^{1}$ & I97 & 17.10 & 0.57 \\
\hline 17.0 & $17.5^{6}$ & 0.9 I 54 & 220 & 19.21 & 1. 65 \\
\hline 18.0 & 18.59 & 0.9157 & $25^{\circ}$ & $21.9^{6}$ & $3 \cdot 36$ \\
\hline 19.0 & 19.63 & $0.9^{1} 59$ & $29^{2}$ & 25.71 & 6.08 \\
\hline 25.0 & 25.83 & 0.9170 & & & \\
\hline
\end{tabular}

Deep-core data, "Byrd" station. Parameters corresponding to computed densities in column 3 are given in columns 4 and 5

0.825 and $0.835 \mathrm{~g} \mathrm{~cm}^{-3}$. Pressure-density data for $\gamma_{\mathrm{c}}=0.825 \mathrm{~g} \mathrm{~cm}^{-3}$ are given in Table I to indicate the method of calculation and also to give the reader some idea of the average bubble pressure associated with any particular density. Curves of bubble pressure and pressure lag $(\Delta P)$ versus absolute load are presented in Figures I and 2. 


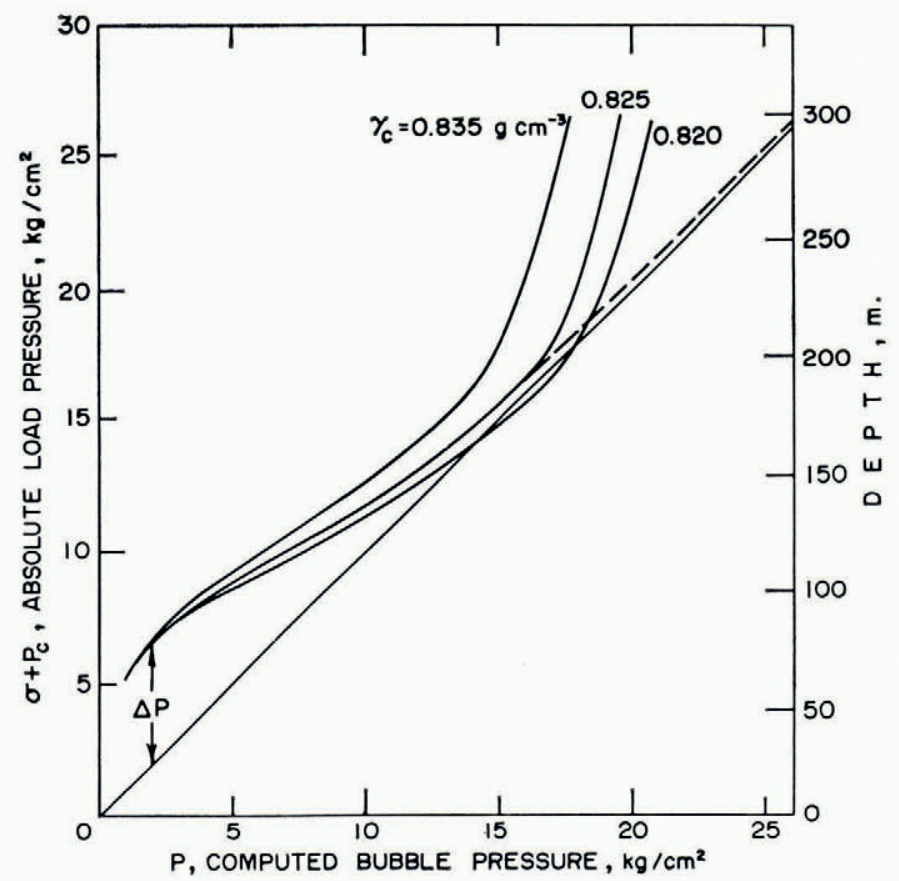

Fig. I. Bubble pressure versus absolute-load pressure at "Byrd" station, Antarctica. The broken line represents the probable trend in in situ ice below $200 \mathrm{~m}$. Divergence at $\sigma+P_{c}>14^{-1} 6 \mathrm{~kg} \mathrm{~cm}^{-2}$ due to expanded (relaxed) condition of samples

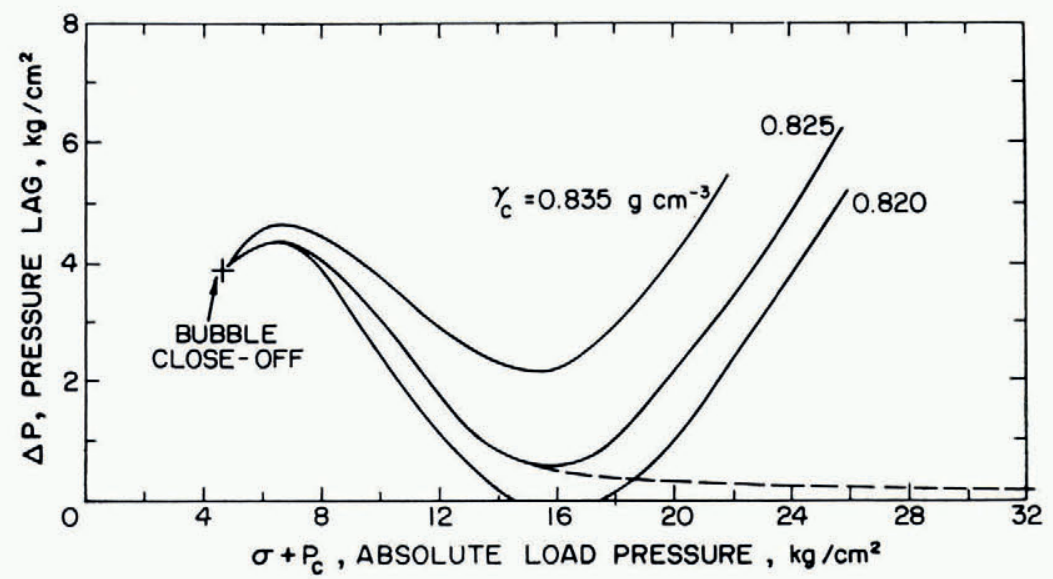

Fig. 2. Bubble-pressure lag $(\triangle P)$ versus absolute-load pressure at "Byrd" station. Data from Figure I

Data obtained with $P_{\mathrm{c}}=0.820 \mathrm{~g} \mathrm{~cm}^{-3}$ are particularly instructive in that the computed bubble pressures actually begin to exceed in situ pressures at a depth of $165 \mathrm{~m}$. This indicates immediately that pore close-off at "Byrd" station must generally occur at densities $>0.820$ $\mathrm{g} \mathrm{cm}^{-3}$. A further feature of the data is the sudden and marked divergence of $\Delta P$ at absoluteload pressures $>15 \mathrm{~kg} \mathrm{~cm}^{-2}$, i.e. deeper than $175 \mathrm{~m}$. This can be due only to an actual expansion of the ice which, in the case of the very deepest samples, is caused by fracturing of the ice during drilling. However, some cores from between 175 and $240 \mathrm{~m}$ contained no 
detectable cracks whatsoever. These samples had "relaxed" to some degree according to density measurements, and the question is immediately raised as to what the mechanism of relaxation is in these particular samples. Langway has attributed identical relaxation of uncracked ice from "Site 2" in Greenland to an actual decompression of the entrapped bubbles (Fig. 3). An inspection of Langway's data for samples tested immediately after drilling and later at intervals of 12 and 18 months indicates that this decompression is confined to samples with bubble pressures $>10 \mathrm{~kg} \mathrm{~cm}^{-2}$. Less compressed bubbles apparently retain their pressures.

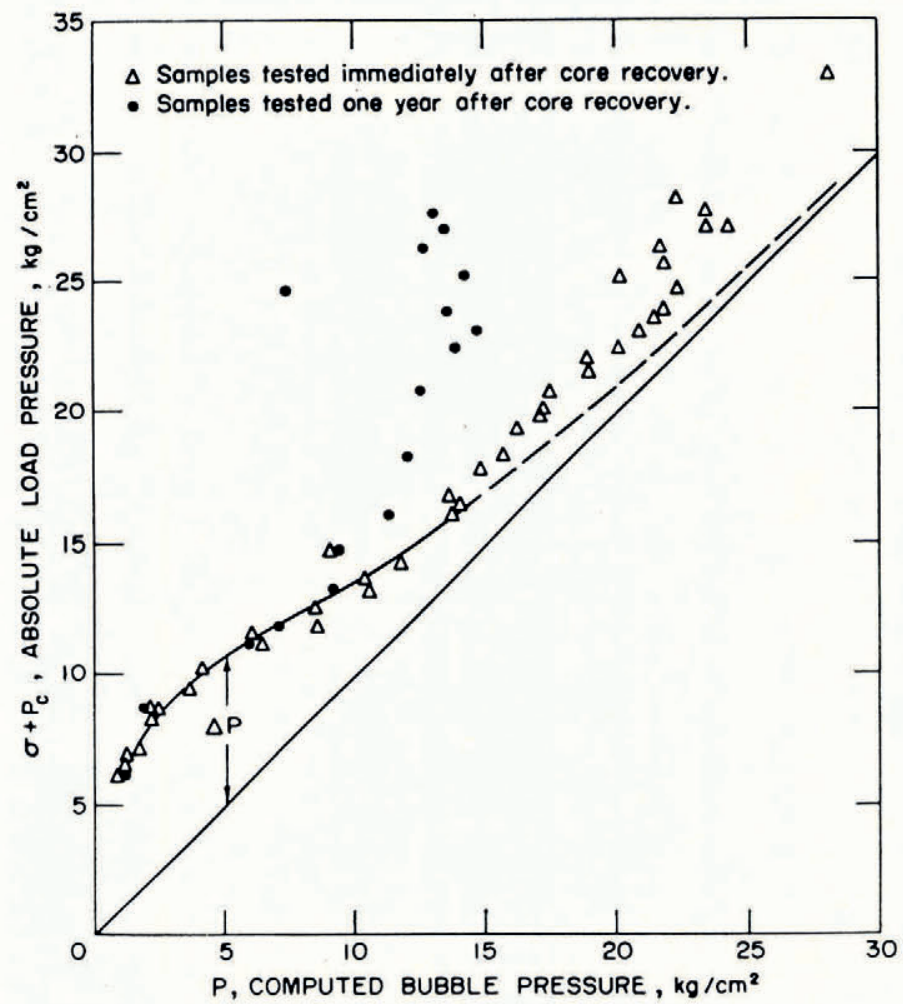

Fig. 3. Bubble pressure versus load pressure at "Site 2", Greenland (from Langway, 1958). Broken line represents probable trend in situ ice below $200 \mathrm{~m}$

In support of his decompression mechanism, Langway cited evidence of the increasing occurrence of small pressure cracks around bubbles in ice from depths $>150 \mathrm{~m}$. Some cracking of bubbles was also observed in the deeper samples at "Byrd" station and at the time it was believed that decompression of cracked bubbles was also the principal mode of relaxation of ice recovered from high confining pressures at "Byrd" station. However, subsequent examination of numerous thin sections of ice from below i $70 \mathrm{~m}$ at "Byrd" station showed that most of the bubbles were not intersected by pressure cracks. Furthermore, actual measurements of the volumes of individual bubbles at various depths in the ice indicated that they were entirely commensurate with in situ pressures. In these samples at least it would appear that relaxation of the ice did not involve any significant decompression of bubbles. The evidence for this will be considered in a later section of this paper dealing with bubble structures in ice at "Byrd" station.

Intuitively one would expect $\Delta P$ to diminish progressively with depth and for the bubble pressure to asymptotically approach the in situ pressure. This trend is certainly indicated in 
results of calculations at "Byrd" station where, for $\gamma_{\mathrm{c}}=0.825 \mathrm{~g} \mathrm{~cm}^{-3}, \Delta P$ diminishes to less than $1.0 \mathrm{~kg} \mathrm{~cm}{ }^{-2}$ at $200 \mathrm{~m}$ depth. This result is encouraging in that it seems to validate the idea that densification beyond pore close-off occurs essentially as the result of compression of entrapped bubbles. A further test of the validity of the pressure-density relationship ( $\mathrm{I}$ ) is provided by the pressure-density data from "Site 2", Greenland. Bader (r965) has given the following parameters for "Site 2 ".

$$
\begin{gathered}
P_{\mathrm{c}}=0.794 \mathrm{~kg} \mathrm{~cm}^{-2}, \\
\gamma_{\mathrm{c}}=0.824 \mathrm{~g} \mathrm{~cm}^{-3}, \\
\gamma_{\mathrm{it}}=0.92002 \mathrm{~g} \mathrm{~cm}^{-3} .
\end{gathered}
$$

Results of computations for some representative pressure-density values of samples tested by Langway immediately after cores were pulled are presented in Table II. From these data it can be seen that measured and computed pressures agree remarkably well and that $\Delta P$

Table II. Bubble-pressure-Load-pressure Relations in Ice Cores from "Site 2", Greenland. Data FROM LANGWAY (1958, 1962) AND BADER (1965)

$\begin{array}{ccccc}\begin{array}{c}\text { Depth } \\ \mathrm{m}\end{array} & \begin{array}{c}\text { Density } \\ \mathrm{g} \mathrm{cm}^{-3}\end{array} & \begin{array}{c}\text { Load pressure } \\ \mathrm{kg} \mathrm{cm}^{-2}\end{array} & \begin{array}{c}\text { Calculated } \\ \text { bubble pressure } \\ \mathrm{kg} \mathrm{cm}^{-2}\end{array} & \begin{array}{c}\text { Measured } \\ \text { buble pressure } \\ \mathrm{kg} \mathrm{cm}^{-2}\end{array} \\ 79.5 & 0.86954 & 6.83 & \mathrm{I} .59 & 1.62 \\ 99.8 & 0.88465 & 8.68 & 2.31 & 2.53 \\ 117.3 & 0.89656 & 10.23 & 3.54 & 3.98 \\ 135.3 & 0.90952 & 11.93 & 8.00 & 8.53 \\ 154.0 & 0.9115 \mathrm{I} & 13.63 & 9.89 & 10.28 \\ 198.0 & 0.91440 & 17.68 & 15.02 & 14.32 \\ 230.7 & 0.91516 & 20.73 & 17.38 & 17.20 \\ 261.8 & 0.91620 & 23.58 & 22.14 & 21.38 \\ 299.2 & 0.91664 & 27.05 & 25.03 & 24.22 \\ 360.5 & 0.91719 & 32.68 & 29.91 & 27.37\end{array}$

diminishes progressively with depth except for the very deepest samples which, as is clearly demonstrated in Figure 3, had already begun to relax before the cores could be pulled to the surface and tested. This increase in $\Delta P$ below $26 \mathrm{I} \mathrm{m}$ is almost certainly due to a volume expansion of samples, though an under-evaluation of as little as $0.003 \mathrm{~g} \mathrm{~cm}^{-3}$ in the original density measurement could account for most of the discrepancy between the calculated bubble pressures in the deepest samples and their in situ pressures.

Because of the unavoidable relaxation of ice from depths greater than $200 \mathrm{~m}$, it becomes increasingly difficult to obtain accurate measurements of in situ density. However, since the difference in pressure between bubbles and overburden is substantially eliminated at about $200 \mathrm{~m}$, one can, by simply substituting the value of $\left(\sigma+P_{\mathbf{c}}\right)$ for $P$ in the pressure-density relationship

$$
\begin{aligned}
\gamma & =\frac{P \gamma_{\mathrm{it}}}{P+P_{\mathrm{c}}\left\{\left(\gamma_{\mathrm{it}} / \gamma_{\mathrm{c}}\right)-\mathrm{I}\right\}} \\
& \simeq \frac{\left(\sigma+P_{\mathrm{c}}\right) \gamma_{\mathrm{it}}}{\sigma+P_{\mathrm{c}}\left(\gamma_{\mathrm{it}} / \gamma_{\mathrm{c}}\right)},
\end{aligned}
$$

compute densities that are considerably more accurate than could ever be measured on deep cores per se. With due allowance for the compressibility of ice, one needs only to know the temperature distribution in an ice sheet in order to obtain very precise values of in situ density. For example, the density of all ice below $400 \mathrm{~m}$ at "Byrd" station can be shown to exceed $0.9180 \mathrm{~g} \mathrm{~cm}^{-3}$, the exact value depending on the temperature and in situ pressure. Ice at the bottom of the ice sheet at "Byrd" station $(2500 \mathrm{~m})$ would have a density of $0.9 \mathrm{I} 83 \mathrm{~g} \mathrm{~cm}^{-3}$, if it was at the pressure melting point $\left(-2.0^{\circ} \mathrm{C}\right)$. This would be a minimum value as any decrease in the temperature of the bottom ice could only increase its density. 
"Little America V"

Progressively increasing temperatures in the Ross Ice Shelf cause a corresponding decrease in $\gamma_{\mathrm{it}}$. In this case it is simpler to compute $P$ for a range of densities using the englacial temperature corresponding to each selected density to determine $\gamma_{i t}$. For example, the density at $83 \mathrm{~m}$ is $0.9040 \mathrm{~g} \mathrm{~cm}^{-3}$. The temperature at this depth is $-2 \mathrm{I}^{\circ} \mathrm{C}$ and the corresponding value of $\gamma_{\mathrm{it}}$ would be $0.9194 \mathrm{~g} \mathrm{~cm}^{-3}$. The average station pressure at "Little America V" (elevation $43 \mathrm{~m})$, corrected for the depth at which the pores finally close off $(52 \mathrm{~m})$, is $\mathrm{I}$.oo $\mathrm{kg} \mathrm{cm}^{-2}$. Pressure-density relations were evaluated for $\gamma_{\mathrm{c}}=0.825$ and $0.835 \mathrm{~g} \mathrm{~cm}^{-3}$, respectively (Fig. 4).

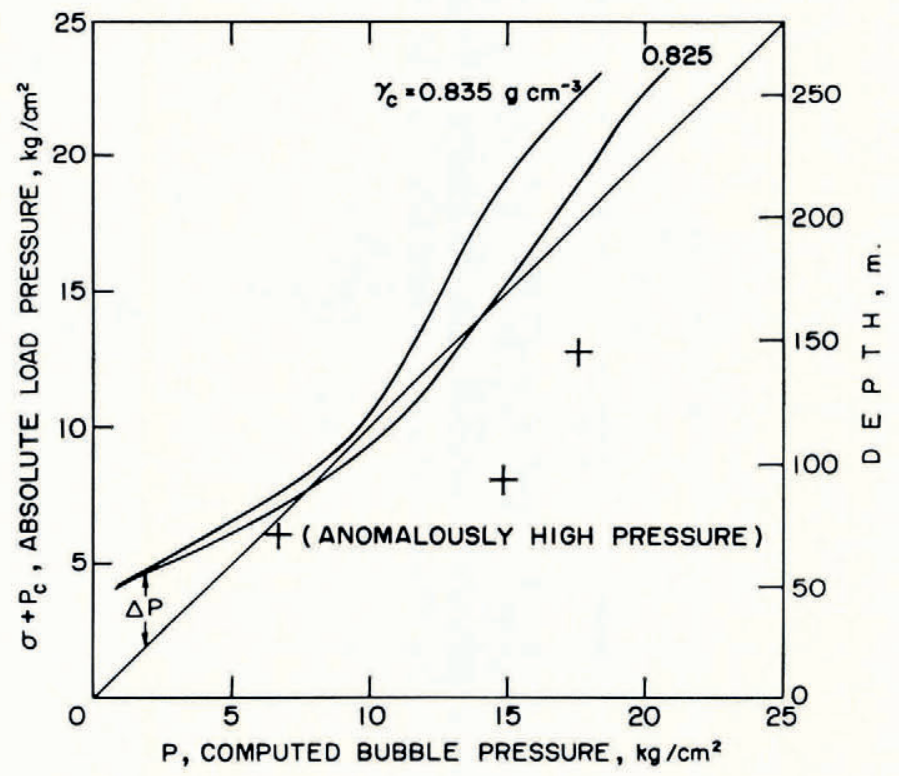

Fig. 4. Bubble pressure versus absolute-load pressure at "Little America V", Ross Ice Shelf, Antarctica

These data tend to confirm abundant stratigraphic and petrographic evidence of the existence of considerable deformation in the Ross Ice Shelf (Gow, I963). It is most unlikely that bubble pressures could ever exceed in situ pressures under normal hydrostatic conditions yet, even for $\gamma_{\mathrm{c}}=0.835 \mathrm{~g} \mathrm{~cm}^{-3}, \Delta P$ is all but eliminated at $\mathrm{I}$ i $8 \mathrm{~m}$ depth at "Little America $\mathrm{V}$ '. For $\gamma_{\mathrm{c}}=0.825 \mathrm{~g} \mathrm{~cm}^{-3}$, the computed bubble pressures actually begin to exceed the in situ pressures at less than $100 \mathrm{~m}$. It should be noted that an exceptional increase in firn densification was also observed below $36 \mathrm{~m}$ at "Little America V" and apparently this anomalous behavior has continued to some depth below the firn-ice transition.

\section{Bubbles IN IGe}

Petrographic studies of Antarctic cores included the preparation of numerous thin sections, several of which were examined in some detail to determine changes in the size, shape and distribution of bubbles as a function of depth in the ice sheet. These studies were conducted primarily on samples from "Byrd" station but some comparative studies were also made of thin sections of cores from "Little America V". The gross differences in crystal-bubble relations at these two locations are clearly demonstrated in Figures 5 and 6. 


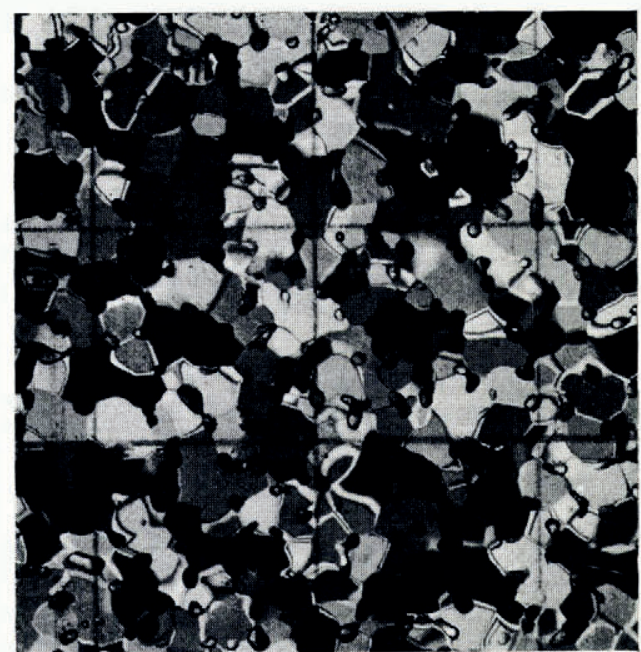

a

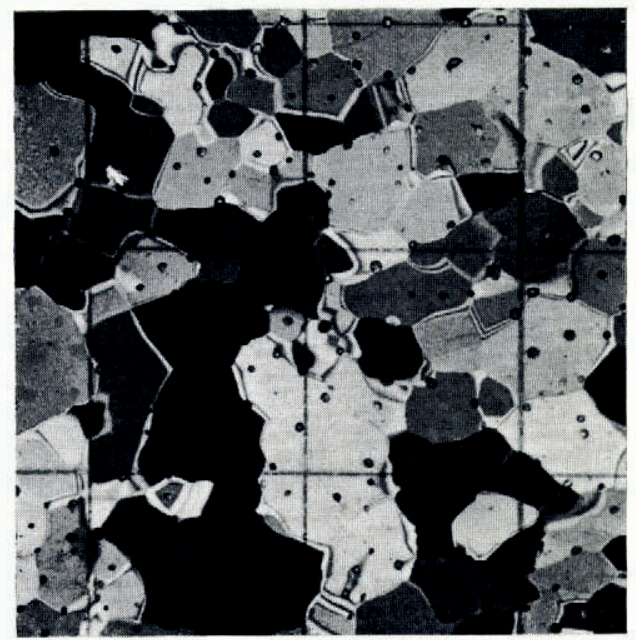

c

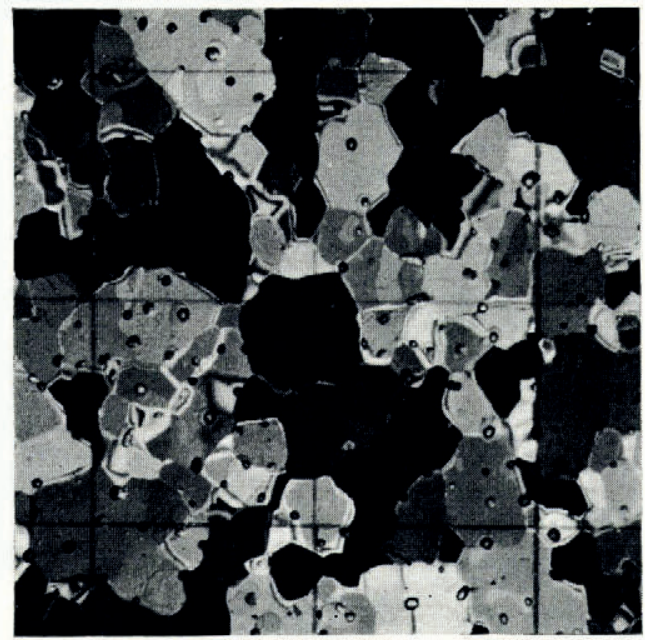

b

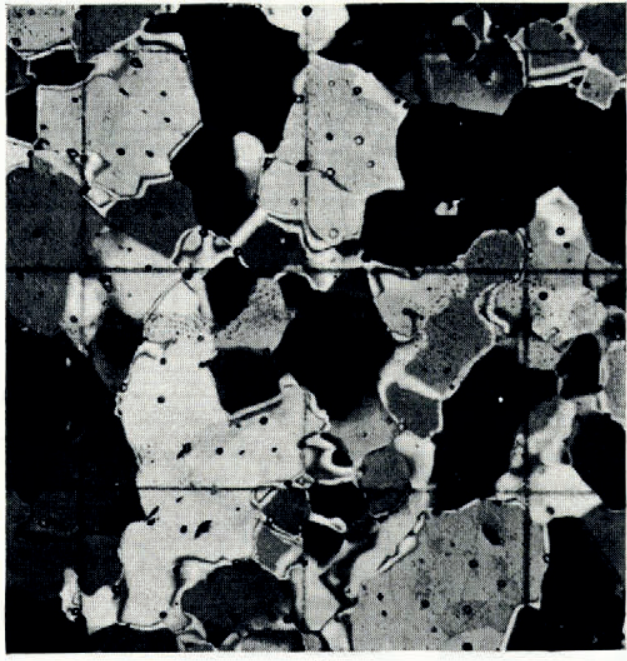

d

Fig. 5. Bubble-crystal relations in ice from "Byrd" station. Bubbles are the small gray and black inclusions located within crystals and at the intersections of crystals. The grid spacing is $1 \mathrm{~cm}$.

a. $70 \mathrm{~m}$ depth; b. ${ }_{11} 6 \mathrm{~m}$ depth; $c$. ${ }_{1} 63 \mathrm{~m}$ depth; $d .305 \mathrm{~m}$ depth

\section{General properties}

In newly formed ice at about $64 \mathrm{~m}$ depth at "Byrd" station the majority of bubbles are located at the intersections of crystals. Bubbles tend to be somewhat irregular at this stage (Fig. 5a) but as the depth of burial increases the bubbles become smaller and spherical. At the same time there is a slow but progressive increase in the size of crystals composing the ice. This growth is obviously to do with grain-boundary migration, but it is of considerable interest to note that during this process there is little if any tendency for the entrapped bubbles of air to be swept towards the grain boundaries. The observation that grain growth is not accompanied by any preferred orientation of the crystals, coupled with the fact that substantially 


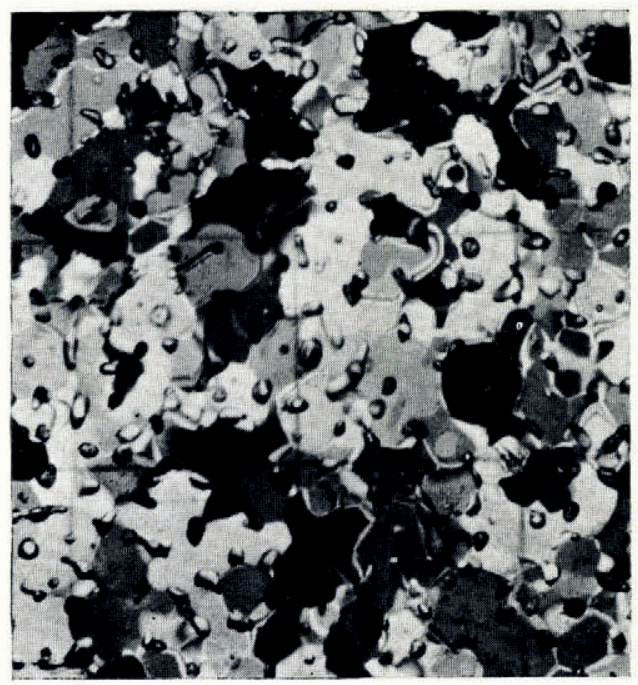

$\mathbf{a}$

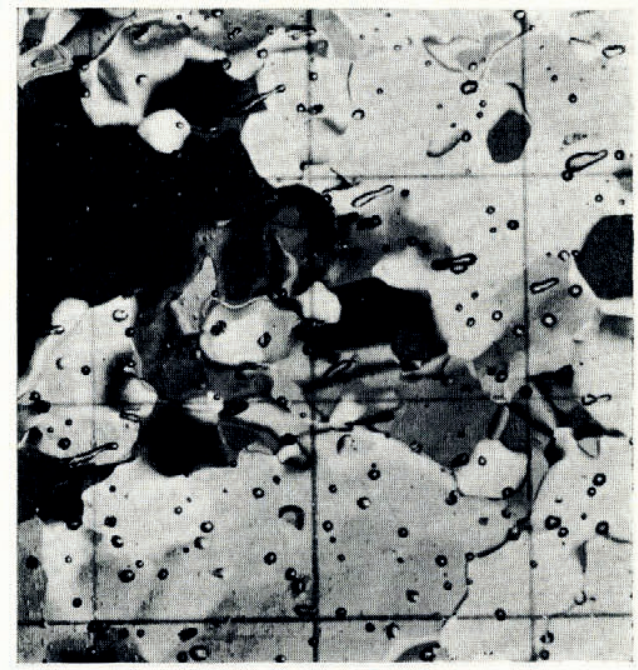

b

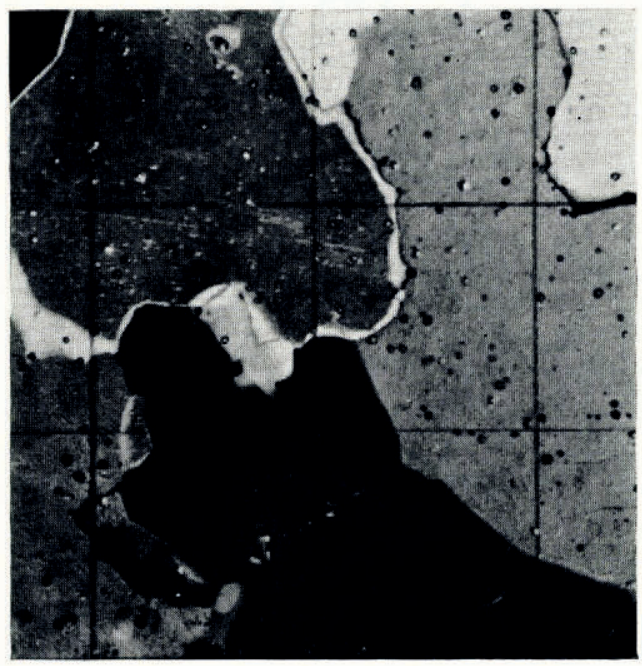

Fig. 6. Bubble-crystal relations in ice from "Little America $V$ ". Note the orientated elongate bubbles at II $6 m$ depth. The grid spacing is $\mathrm{I} \mathrm{cm}$.

a. $52 \mathrm{~m}$ depth; b. $116 \mathrm{~m}$ depth; c. $240 \mathrm{~m}$ depth

spherical bubbles only are formed at depth, is a strong indication that stress conditions in the ice at "Byrd" station are essentially hydrostatic.

The number of bubbles in a unit volume of ice appears to remain constant which means that as the size of crystals increases so does the number of bubbles within a crystal. A count of the average number of bubbles in crystals in sections of given thickness from various depths in the ice thus affords a relatively rapid yet reliable means of estimating the rate of growth of crystals in the ice sheet.

Whereas crystal-bubble patterns in the ice at "Byrd" station appear to have evolved under essentially hydrostatic conditions, those at "Little America 'V" have not. Here, 
englacial deformation has caused an appreciable orientating of bubbles as well as crystals. Elongate and "waisted" bubbles are especially well developed in ice from between roo and $130 \mathrm{~m}$ (Fig. 6b) and crystals generally are much larger than those at comparable depths at "Byrd" station. Numerous highly compressed spherical bubbles characterize ice in the deepest cores, but as can be observed in Figures $5 \mathrm{~d}$ and $6 \mathrm{c}$ only a relatively small proportion of these bubbles is actually intersected by pressure cracks.

\section{Bubble dimensions}

Measurements of bubble dimensions were confined to sections of ice from "Byrd" station. These measurements were made on photomicrographs rather than on the thin sections themselves and, in order to further simplify the measurements, only those sections in which most of the bubbles had become spherical were used, i.e. sections from i $6 \mathrm{~m}$ and deeper. All sections examined contained several hundred bubbles but only those bubbles located close to the upper surface of a section were used for measuring diameters. Fifty bubbles from each of five selected depths were measured and the results of these determinations are presented in Table III. From these data it can be seen that the average bubble diameter decreased from $0.49 \mathrm{~mm}$ at $\mathrm{I}$ I $6 \mathrm{~m}$ to $0.33 \mathrm{~mm}$ at $279 \mathrm{~m}$. This corresponds to a decrease in the volume of individual bubbles of from 0.062 to $0.019 \mathrm{~mm}^{3}$.

Table III. Bubble Dimensions in Glacier Ice from “Byrd” Station, Antarctica

\begin{tabular}{|c|c|c|c|c|}
\hline Depth of sample & $\begin{array}{c}\text { Average } \\
\text { bubble diameter }\end{array}$ & Bubble volume & Porosity & $\begin{array}{c}\text { Number of } \\
\text { bubbles/cm } 3 \text { of ice }\end{array}$ \\
\hline I1 6 & 0.490 & 0.062 & $1.4 \mathrm{I}$ & 228 \\
\hline 135 & 0.439 & 0.045 & $\begin{array}{l}1.41 \\
1.01\end{array}$ & 226 \\
\hline 163 & 0.393 & 0.031 & 0.72 & 231 \\
\hline$*_{215}$ & 0.342 & 0.021 & 0.500 & 239 \\
\hline$*_{279}$ & 0.333 & 0.019 & $0.39^{1}$ & 202 \\
\hline
\end{tabular}

* Porosities at these depths have been corrected for the effects of elastic relaxation of the ice.

Since the porosity of a sample of ice can be readily ascertained from its density, these data on bubble volumes can also be used to determine the average number of bubbles present in a unit volume of ice. Results of these computations (Table III) show that the concentration of bubbles at various depths in the ice sheet at "Byrd" station remains remarkably constant at between 200 and 240 bubbles $/ \mathrm{cm}^{3}$ - further proof too that there is little if any tendency for entrapped air bubbles to migrate or coalesce during recrystallization of the ice.

The above data can also be used to obtain a reliable estimate of the average size of the equivalent spherical bubble at pore close-off. Because of the irregular shapes of bubbles at this depth, it is not practical to attempt to determine bubble dimensions directly. Since the porosity at close-off is $\approx$ Io per cent, I $\mathrm{cm}^{3}$ of sample will contain $\mathrm{I} 00 \mathrm{~mm}^{3}$ of entrapped air. Using a value of 220 bubbles $/ \mathrm{cm}^{3}$ (the average count obtained from measurements on the five samples from i $6 \mathrm{~m}$ and deeper), it is found that the mean volume of the equivalent spherical bubble at pore close-off at "Byrd" station is $0.45 \mathrm{~mm}^{3}$. Its diameter would be $0.95 \mathrm{~mm}$.

\section{Bubble-crystal relations}

With data already obtained on crystal-size variations with depth at "Byrd" station (Gow, I964), the relationship between the number of bubbles and crystals at pore close-off can now be determined. Average crystal cross-sections between 6I and $66 \mathrm{~m}$ at "Byrd" station varied from 3.1 to $3.7 \mathrm{~mm}^{2}$. If a value of $3.4 \mathrm{~mm}^{2}$ is taken and, it is assumed for simplicity, that the sections are hemispherical, then the volume of the corresponding spherical crystal will be $4.7 \mathrm{I} \mathrm{mm}$. If crystals of these dimensions could be deformed-packed into the remaining 
$900 \mathrm{~mm}^{3}$ of space in $\mathrm{I} \mathrm{cm}^{3}$ of ice, then the number of crystals at close-off would be $900 / 4.7 \mathrm{I}=\mathrm{I} 9 \mathrm{I}$. The number of bubbles in the same $\mathrm{I} \mathrm{cm} \mathrm{cm}^{3}$ of ice is $\approx 220$, from which it can be concluded that at pore close-off there are approximately as many crystals present as bubbles. One interesting aspect of this result is that it does tend to demonstrate that the I : I relationship between voids and particles observed in systematically packed aggregates of equidimensional particles also holds for naturally dense-packed structures. As it turns out the crystal-pore structure at the firn-ice transition probably conforms as closely to a densepacked aggregate as any in nature.

A further implication of the above result is that any change in the number of crystals per cubic centimeter at the firn-ice transition should be accompanied by a corresponding change in the number and size of bubbles. For example, firn crystal-growth studies to a depth of $50 \mathrm{~m}$ at the South Pole (Gow, unpublished) have shown that the mean crystal cross-section increases essentially linearly with depth at the rate of $0.005 \mathrm{~mm}^{2} \mathrm{~m}^{-1}$. At $50 \mathrm{~m}$ the mean cross-sectional area of crystals was $0.65 \mathrm{~mm}^{2}$ which, if extrapolated to the depth of the firn-ice transition at I I $\mathrm{m}$ (estimated) gives a mean crystal cross-section of $0.95 \mathrm{~mm}^{2}$. I cm of ice at I Io m would thus contain nearly i 400 crystals. This would represent a seven-fold increase in the number of crystals and bubbles over that observed at "Byrd" station but, since the total available pore space is still the same $(\approx$ io per cent $)$, the bubbles at pore close-off at the South Pole should be much smaller, of the order $0.5 \mathrm{~mm}$ in diameter compared with $0.95 \mathrm{~mm}$ for the diameter of the equivalent spherical bubble at "Byrd" station. On the other hand, estimates of bubble dimensions based on crystal-size data at pore close-off at a number of other locations in Antarctica indicate that at "Wilkes S-2" the number of bubbles should be much the same as at "Byrd" station $\left(\approx 200\right.$ bubbles $\left./ \mathrm{cm}^{3}\right)$, increasing to about 300 bubbles/ $\mathrm{cm}^{3}$ at Maudheim and to $35^{\circ}$ bubbles $/ \mathrm{cm}^{3}$ at "Southice". Of course, the size and number of crystals and bubbles at pore close-off will depend upon the rate of densification, which in turn depends on the rate of accumulation and the mean annual temperature. In general, however, it would appear that the bubbliness of ice as determined by the number of bubbles $/ \mathrm{cm}^{3} \mathrm{should}$ increase towards the center of the Antarctic ice sheet.

\section{Relaxation of ice}

Measurements of bubble volume also provide an independent check on whether bubbles in the deepest ice have undergone any significant decompression. The original thin sections were prepared from samples that had lain in storage for more than a year-ample time for measurable relaxation to have occurred prior to sectioning. Since there is no evidence that bubbles with pressures $<10 \mathrm{~kg} \mathrm{~cm}^{-2}$ undergo any significant decompression (Langway, 1958), pressure-volume data for ice from either i 6 or $135 \mathrm{~m}$ can be used to evaluate average bubble pressures in samples of deeper ice from "Byrd" station. Computations of bubble pressure $P$ ' based on data from I $6 \mathrm{~m}$ are presented in Table IV. The two pressure values at each depth agree remarkably well. All indications from the data in Table IV are that no significant decompression of entrapped air bubbles has occurred in the cores from "Byrd" station.

Table IV. Bubble Volume-Pressure Relationships in Glacier Ice from "Byrd" Station, Antarctica 
Pressure cracking of bubbles could possibly occur in cores of very deep ice and, in view of the present attempt to drill to the bottom of the Antarctic ice sheet at "Byrd" station, this possibility seems worth investigating. The separation distance between neighboring bubbles in the ice as well as the stress associated with a particular bubble pressure both need to be considered. This stress in ice tending to split bubbles apart might be calculated as follows:

Let the volume $V$ of some bubble at pressure $P$ be $V=\frac{4}{3} \pi r^{3}$, where $r$ is the radius of the bubble. Now let this bubble be surrounded by a sphere of ice of radius $R$ such that the

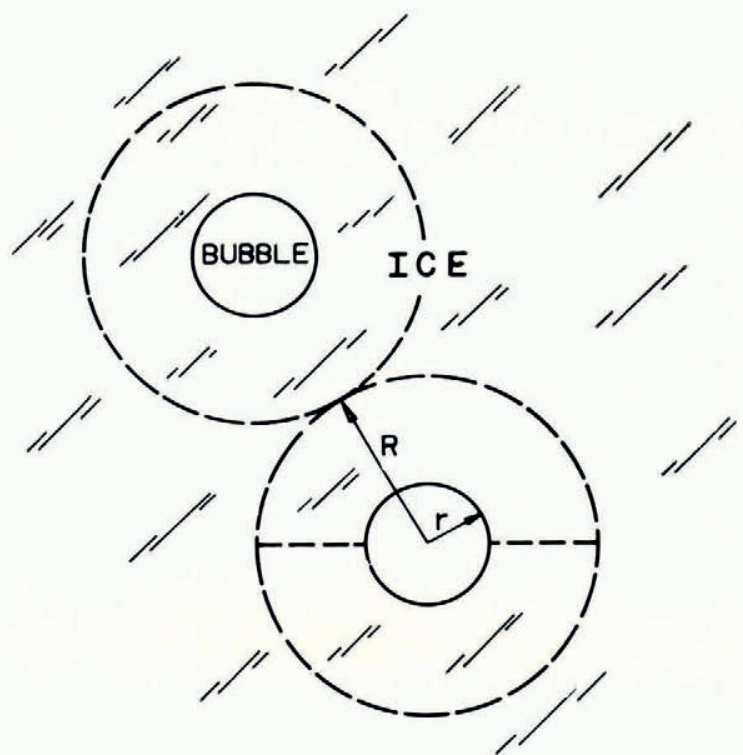

Fig. 7. Schematic diagram of two pressurized bubbles of radius $r$ in glacier ice. Distance between bubble centers is $2 R$

average distance between neighboring bubbles is $2 R$ (Fig. 7). The total force trying to split apart the two hemispheres of ice defined by the dashed line is $F=\pi r^{2} P$.

The area of the interface across which this force acts is

Accordingly,

$$
\begin{aligned}
A & =\pi R^{2}-\pi r^{2}, \\
& =\pi\left(R^{2}-r^{2}\right) .
\end{aligned}
$$

$$
\begin{aligned}
\frac{F}{A} & =\frac{\pi r^{2} P}{\pi\left(R^{2}-r^{2}\right)}, \\
& =P \frac{r^{2}}{R^{2}-r^{2}} .
\end{aligned}
$$

If the rupture stress of the ice is $S=F^{\star} / A$, then the maximum allowable bubble pressure is

$$
\begin{aligned}
P^{\star} & =F^{\star} / A\left(\frac{R^{2}-r^{2}}{r^{2}}\right), \\
& =S\left[\left(\frac{R}{r}\right)^{2}-\mathrm{I}\right] \mathrm{kg} \mathrm{cm^{2 } .}
\end{aligned}
$$

According to the data of Butkovich (1959), the tensile strength of glacier ice of density $>0.900 \mathrm{~g} \mathrm{~cm}^{-3}$ generally lies between 20 and $30 \mathrm{~kg} \mathrm{~cm}^{-2}$. If the lower value is taken, then

$$
P^{\star}=20\left[(R / r)^{2}-\mathrm{I}\right] \text {. }
$$


Before the above relationship can be evaluated it is necessary to know something of the manner of distribution of bubbles in the ice at "Byrd" station. A fairly uniform distribution of bubbles seems reasonable, at least on the basis of observations at pore close-off where the vast majority of bubbles were observed to be located at the intersections of essentially equidimensional crystals. The very simplest distribution would involve an arrangement of layers in which the distance between bubbles in the same layer is the same as the spacing between layers. In the particular case of 220 bubbles $/ \mathrm{cm}^{3}$ (average concentration of bubbles observed at "Byrd" station), this spacing would be $\mathrm{I} / 22 \mathrm{O}^{\frac{1}{3}} \mathrm{~cm}=\mathrm{I} .7 \mathrm{~mm}$, i.e. approximately six layers of 36 bubbles each in $1 \mathrm{~cm}^{3}$ of ice. At pore close-off, where the mean diameter (2r) of bubbles is $0.95 \mathrm{~mm}, R / r$ is 1.7 , increasing to 5.1 at $279 \mathrm{~m}$. These and intermediate values at "Byrd" station, together with the calculated values of $P^{\star}=20\left[(R / r)^{2}-\mathrm{I}\right]$, are presented in Table V. From the data listed in Table V it would appear that the stress in ice due to bubble pressure is much too low to cause the ice to fracture.* In practice, of course, some small fraction of bubbles would be situated at less than the critical distance, in which case fracturing of the intervening ice could be expected to occur. The values $R / r$ (critical) needed to attain this condition at various depths in the ice at "Byrd" station are also listed in Table V. It

Table V. Estimate of Maximum Allowable Pressure $\left(P^{\star}\right)$ in Bubbles in Glacier Ice at "Byrd" Station. Pressures Calculated According to the Relation $P^{\star}=20\left[(R / r)^{2}-1\right]$. See Text for Derivation

$\begin{array}{rrccc}\text { Depth } & R / r & P^{\star} & P(\text { estimated }) & R / r \text { (critical) } \\ 64 & 1.7 & 32 & 0.8 & 1.03 \\ 116 & 3.4 & 180 & 6 & 1.16 \\ 163 & 4.4 & 313 & 13 & 1.33 \\ 279 & 5.1 & 425 & 19 & 1.46 \\ 2500 & \text { I0.0 } & 1683 & 225 & 3.96\end{array}$

should be noted, however, that when bubbles are intersected by pressure cracks these cracks invariably occur parallel to the basal planes of crystals. Such a favored orientation demonstrates further the inherent weakness within the basal plane and it is likely that the rupture stress in this plane is appreciably smaller than in other directions in ice. Nevertheless the rupture stress would need to decrease by more than an order of magnitude for any widespread fracturing to occur under these conditions. In the case of those deep-core samples which are known to have undergone measurable expansion, but which have done so without any detectable cracking, it may be necessary to invoke some process of micro-fracturing to account for the expansion. Cracks formed in this way might be so small as to pass unnoticed, though it may only require a sharp knock or some other source of mechanical shock, e.g. undampened vibrations in the drill string for such micro-cracks to propagate into large visible fractures.

Up to now the feeling has been that ice from deep within an ice sheet would literaily explode in the core barrel because of rapid decompression of the entrapped air bubbles. However, from the results given above, it would now appear that with the proper precautions it should be possible to obtain usable cores to considerable depths in the Antarctic ice sheet. This would be best accomplished in a liquid-loaded hole such as the one that is now being drilled at "Byrd" station and which hopefully will penetrate to the bottom of the ice sheet. In this type of deep drilling it is necessary to load the hole with liquid of approximately the same density as ice so as to prevent the walls of the hole from closing. However, there are additional advantages to this system. A liquid-loaded hole dampens out virtually all vibrations in the drill string thus reducing the risk of mechanical breakage of ice cores during drilling. More important perhaps is the fact that the liquid load maintains pressure on the ice during the actual process of coring thus preventing any immediate relaxation of the ice. Since preparing the first draft of this manuscript a U.S. Army CRREL drill team has success-

* A similar conclusion was reached using the formula for so-called thick-walled spherical vessels given by Roark (1954), though it is questionable whether this formula is valid for the very thick shells envisaged here. 
fully cored to the bottom ( $1390 \mathrm{~m}$ ) of the Greenland ice sheet at "Camp Century" (Hansen and Langway, I 966). A preliminary inspection of cores from near the bottom of the hole (liquid loaded) showed little if any fracturing of the ice and there were no immediate signs of any significant decompression of entrapped air bubbles even though in situ pressures near the bottom of the ice sheet at "Camp Century" probably exceed $100 \mathrm{~kg} \mathrm{~cm}^{-2}$.

\section{Conclusions}

Densification of bubbly ice after pore close-off is due almost entirely to compression of the entrapped air bubbles. This relationship between the bulk density $\gamma$ of the ice and the pressure $P$ of its inclosed bubbles can be expressed as follows:

$$
\gamma=\frac{P \gamma_{\mathrm{it}}}{P+P_{\mathrm{c}}\left(\frac{\gamma_{\mathrm{it}}}{\gamma_{\mathrm{c}}}-\mathrm{I}\right)},
$$

where $\gamma_{\mathrm{it}}$ is the density of bubble-free ice at the englacial temperature and $P_{\mathrm{c}}$ and $\gamma_{\mathrm{c}}$ are the bubble pressure and density respectively of the ice at pore close-off. Computations of bubble pressure in ice cores from "Byrd" station, Antarctica, indicate that the pressure lag $\Delta P$ between bubbles and the absolute load, initially $4-5 \mathrm{~kg} \mathrm{~cm}^{-2}$ at pore close-off (64 $\mathrm{m} \mathrm{depth}$ ), diminishes to less than $\mathrm{I} .0 \mathrm{~kg} \mathrm{~cm}^{-2}$ at $200 \mathrm{~m}$. A direct consequence of this result is that by substituting the absolute-load pressure, $\sigma+P_{\mathrm{c}}$, for $P$ in the above relationship one can determine ice densities below $200 \mathrm{~m}$ more accurately than can be obtained with measurements per se on the cores because of the unavoidable relaxation of the latter following their removal from high confining pressures. This relaxation of the ice is generally attributed to decompression of the entrapped air bubbles. However, calculations of the stresses in the ice due to bubble pressure together with actual measurements of bubble volumes in "relaxed" cores from "Byrd" station tend to indicate that there is little if any significant decompression of bubbles even in ice recovered from very high confining pressures. Apparently the observed increase in bulk volume of ice samples with time does not depend upon prior expansion of bubbles. These data point up the need for further investigations of the mechanics of relaxation of ice recovered from high confining pressures.

Bubble pressure-density relations in ice cores at "Little America V" indicate anomalously high bubble pressures in the upper layers of the Ross Ice Shelf. These data tend to confirm the abundant stratigraphic and petrographic evidence for the existence of very considerable deformation near the seaward edge of the Ross Ice Shelf.

Antarctic glacier ice is characterized by an abundance of air bubbles. Measurements on ice from "Byrd" station show that the concentration of bubbles remains remarkably constant at $200-240$ bubbles $/ \mathrm{cm}^{3}$ of ice. At the pore close-off depth at $64 \mathrm{~m}$ the ice was observed to contain approximately the same number of crystals as bubbles. The mean diameter of air bubbles at this depth was $0.95 \mathrm{~mm}$, decreasing to $0.49 \mathrm{~mm}$ at $\mathrm{I} 16 \mathrm{~m}$ and to $0.33 \mathrm{~mm}$ at $279 \mathrm{~m}$. A very uniform distribution of bubbles was observed at all depths. Bubbles showed no tendency to be swept towards grain boundaries during recrystallization of the ice. These observations and the fact that the majority of bubbles had become spherical at a depth of less than $120 \mathrm{~m}$ would also tend to indicate the existence of essentially hydrostatic conditions in the upper part of the ice sheet at "Byrd" station. By contrast, the formation of numerous elongate bubbles orientated symmetrically with respect to well-formed fabrics in ice between 90 and I $30 \mathrm{~m}$ at "Little America V" is compatible only with the existence of considerable shearing in the ice shelf.

\section{Acknowledgements}

This research was accomplished in conjunction with a U.S. Army Cold Regions Research and Engineering Laboratory research project devoted to deep core-drilling studies in 
Antarctica. The project was sponsored by the U.S. Antarctic Research Program and supported by grants from the National Science Foundation. The support of these institutions, together with the assistance in the field of Task Force 43, U.S. Navy, is gratefully acknowledged. The author is indebted to Mr B. Lyle Hansen and Dr Chester C. Langway, Jr., for helpful discussions and for critically reviewing the manuscript.

MS. received 8 August 1967

\section{REFERENCES}

Bader, H. 1950. The significance of air bubbles in glacier ice. Fournal of Glaciology, Vol. 1, No. 8, p. 443-51 .

Bader, H. 1965. Theory of densification of dry, bubbly glacier ice. U.S. Cold Regions Research and Engineering Laboratsry. Research Report $14 \mathrm{I}$.

Butkovich, T. R. 1957. Linear thermal expansion of ice. U.S. Snow, Ice and Permafrost Research Establishment. Research Report 40.

Butkovich, T. R. 1959. Some physical properties of ice from the Tuto Tunnel and Ramp, Thule, Greenland. U.S. Snow, Ice and Permafrost Research Establishment. Research Report 47.

Coachman, L. K., and others. 1956. Gas enclosures in a temperate glacier, by L. K. Coachman, E. Hemmingsen and P. F. Scholander. Tellus, Vol. 8, No. 4, p. 415-23.

Gow, A. J. 1963. The inner structure of the Ross Ice Shelf at Little America V, Antarctica, as revealed by deep core drilling. Union Géodésique et Géophysique Internationale. Association Internationale d'Hydrologie Scientifique. Assemblée générale de Berkeley, $19-3-31-31963$. Commission des Neiges et des Glaces, p. 272-84.

Gow, A. J. 1964. Profile studies. (In Bentley, C. R., and others. Physical characteristics of the Antarctic ice sheet, by C. R. Bentley, R. L. Cameron, C. Bull, K. Kojima and A. J. Gow. Antarctic Map Folio Series (New York, American Geographical Society), Folio 2, p. 4-6.)

Gow, A. J. In press. Deep core studies of the accumulation and densification of snow at Byrd station and Little America V, Antarctica. U.S. Cold Regions Research and Engineering Laboratory. Research Report 197.

Gow, A. J. Unpublished. On the rates of growth of grains and crystals in South Polar firn.

Hansen, B. L., and Langway, C. C., jr. 1966. Deep core drilling in ice and core analyses at Camp Century, Greenland, 1961-1966. Antarctic Journal of the United States, Vol. I, No. 5, p. 207-08.

Koch, J. P., and Wegener, A. 1930. Wissenschaftliche Ergebnisse der dänischen Expedition nach Dronning Louises-Land und quer über das Inlandeis von Nordgrönland, 1912-13. Meddelelser om Gronland, Bd. 75 .

Langway, C. C., jr. 1958. Bubble pressures in Greenland glacier ice. Union Géodésique et Géophysique Internationale. Association Internationale d'Hydrologie Scientifique. Symposium de Chamsnix, I6-24 sept. 1958, p. 336-49.

Langway, C. C., jr. 1962 . Some physical and chemical investigations of a 411 meter deep Greenland ice core and their relationship to accumulation. Union Géodésique et Géophysique Internationale. Association Internationale d'Hydrologie Scientifique. Commission des. Neiges et Glaces. Colloque d'Obergurgl, $10-9-18-9$ I962, p. 101-18.

Matsuo, S., and Miyake, Y. 1966. Gas composition in ice samples from Antarctica. Fournal of Geophysical Research, Vol. 71, No. 22, p. 5235-41.

Roark, R. J. 1954. Formulas for stress and strain. New York, McGraw-Hill.

Scholander, P. F., and Nutt, D. C. 1960. Bubble pressure in Greenland icebergs. Journal of Glaciology, Vol. 3, No. 28, p. $671-78$.

Scholander, P. F., and others. 1956. Gases in icebergs, by P. F. Scholander, J. W. Kanwisher and D. C. Nutt. Science, Vol. 123, No. 3186, p. $104-05$.

Schytt, V. 1958. Glaciology. II. A. Snow studies at Maudheim.-B. Snow studies inland.-C. The inner structure of the ice shelf at Maudheim as shown by core drilling. Norwegian-British-Swedish Antarctic Expedition, 1949-52. Scientific Results, Vol. 4.

Shumskiy, P. A. 1955. Osnovy strukturnogo ledovadeniya. Petrografiya presnogo l'da kak metod glyatsiologicheskogo issledovaniya. Moscow, Izdatel'stvo Akademii Nauk SSSR. [English translation: Principles of structural glaciology: the petrography of fresh-water ice as a method of glaciological investigation. Translated from the Russian by David Kraus. New York, Dover Publications, 1964.] 